\title{
Afroasiatic Language
}

National Cancer Institute

\section{Source}

National Cancer Institute. Afroasiatic Language. NCI Thesaurus. Code C160955.

A large language family of about 300 languages, including languages spoken

predominantly in West Asia, North Africa, the Horn of Africa and parts of the Sahel. 